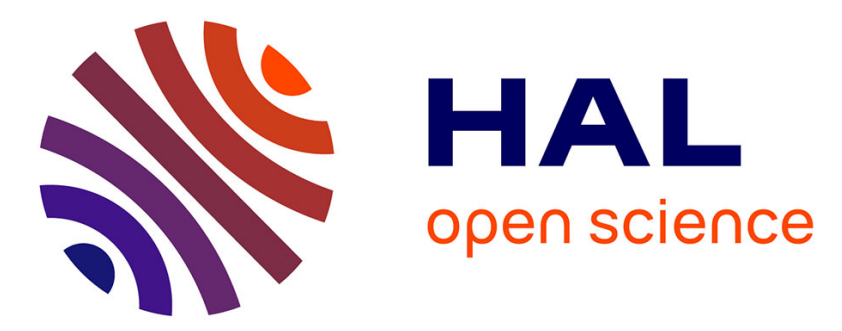

\title{
Morphology and photochemical stability of P3HT:PCBM active layers of organic solar cells
}

\author{
A. Dupuis, A. Tournebize, Pierre-Olivier Bussiere, Agnès Rivaton, Jean-Luc \\ Gardette
}

\section{- To cite this version:}

A. Dupuis, A. Tournebize, Pierre-Olivier Bussiere, Agnès Rivaton, Jean-Luc Gardette. Morphology and photochemical stability of P3HT:PCBM active layers of organic solar cells. European Physical Journal: Applied Physics, 2011, 56 (3), pp.34104. 10.1051/epjap/2011110132 . hal-00756411

\author{
HAL Id: hal-00756411 \\ https://hal.science/hal-00756411
}

Submitted on 23 Nov 2012

HAL is a multi-disciplinary open access archive for the deposit and dissemination of scientific research documents, whether they are published or not. The documents may come from teaching and research institutions in France or abroad, or from public or private research centers.
L'archive ouverte pluridisciplinaire HAL, est destinée au dépôt et à la diffusion de documents scientifiques de niveau recherche, publiés ou non, émanant des établissements d'enseignement et de recherche français ou étrangers, des laboratoires publics ou privés. 


\title{
Morphology and photochemical stability of P3HT:PCBM active
}

\section{layers of organic solar cells}

\author{
Aurélie Dupuis a,b, Aurélien Tournebize ${ }^{\mathrm{a}, \mathrm{b}}$, Pierre-Olivier Bussière ${ }^{\mathrm{a}, \mathrm{b}, \mathrm{c}}$, Agnès Rivaton ${ }^{\mathrm{a}, \mathrm{b}^{*}}$, \\ Jean-Luc Gardette ${ }^{\text {a,b }}$ \\ ${ }^{a}$ Clermont Université, Université Blaise Pascal, Laboratoire de Photochimie Moléculaire et \\ Macromoléculaire (LPMM), BP10448, F-63000 Clermont-Ferrand, France \\ ${ }^{\mathrm{b}}$ CNRS, UMR6505, LPMM, F-63177 Aubière, France \\ ${ }^{\mathrm{c}}$ Clermont Université, ENSCCF, Laboratoire de Photochimie Moléculaire et \\ Macromoléculaire, BP 10448, F-63000 Clermont-Ferrand, France
}

\begin{abstract}
We report on the effects of continuous UV-visible light illumination at $60^{\circ} \mathrm{C}$ in the absence of oxygen on P3HT:PCBM blend films commonly used active layer of bulk heterojunction solar cells. A full description of the behavior of P3HT:PCBM blend films either unconfined or confined by an Al cathode and a PEDOT:PSS layer during annealing treatment and irradiation is provided. We also focused on the impact of the P3HT-type on the photostability. It was shown that the microstructure of P3HT dramatically influenced the photodegradation process of P3HT thin films deposited on inert substrate. The rate of photodegradation process was decreased when P3HT was blended with PCBM. It was shown that the photostability of the

\footnotetext{
"Corresponding author: Clermont Université, Université Blaise Pascal, Laboratoire de Photochimie Moléculaire et Macromoléculaire (LPMM), BP10448, F-63000 Clermont-Ferrand, France. Tel.: +33 4734077 43; fax: +33 4 73407700 .

E-mail address: agnes.rivaton@univ-bpclermont.fr (A. Rivaton).
} 
active layer was not influenced by a PEDOT-PSS sub-layer. Solar cells were then fabricated from high-regioregular P3HT. Many large PCBM crystals were observed in P3HT:PCBM blend films and it was shown that the top surface of the active layer in contact with the $\mathrm{Al}$ cathode was nearly entirely composed of P3HT. Both results account for the low performances of the devices. Finally, photo-ageing experiments provoked a rapid failure of the Al cathodes which was tentatively attributed to an increase of internal strain within the devices.

Keywords: P3HT; PCBM; organic solar cells; photochemical stability; Al cathode, morphology, interfacial behavior

\section{Introduction}

Research and commercialization of polymers as electronically active and inactive supports for organic solar cells (OSCs) is expected to undergo explosive growth in the short- to mediumterm future $[1,2]$. Polymer-based OSCs are attractive alternatives to silicon technology, due to their relatively low cost, flexibility, coloration, and semi-transparency [3], these properties making them ideal candidates for building integrated applications. To compete with silicon devices, intense efforts have been aimed at improving the power conversion efficiency of OSCs, which reached 8,3\% last year [4]. However, current OSCs only fit niche-markets due to reduced lifetimes.

OSCs lifetimes must be improved before large-scale industrialization can take place [5]. The understanding of OSC failure mechanisms has recently built a foundation of knowledge. OSCs exhibit low resistance to the combined actions of sunlight, temperature, $\mathrm{O}_{2}$, and $\mathrm{H}_{2} \mathrm{O}$. Ageing occurs at each layer and interface [6]. The photochemical stability of the polymer active layer is one aspect of the complex OSCs stability problem, and three points have to be taken into consideration: 
(i) Almost all organic polymers are unstable under UV light irradiation at ambient air [7-9]. Photodegradation of polymeric materials is strongly attenuated when irradiations are performed in the absence of oxygen. This was recently evidenced in the case of both MDMO-PPV (poly[2-methoxy-5-(3',7'-dimethyloctyloxy)-1,4-phenylenevinylene) and P3HT poly(3-hexyl thiophene) $[10,11]$. It was also shown that the degradation rate dramatically decreases when the conjugated polymer is blended with fullerene derivatives such as PCBM ([6,6]-phenyl C61butyric acid methyl ester) [10,11]. This effect comes from both the radical scavenging properties of the fullerene and its ability to quench the polymer singlet state $[10,11]$.

(ii) Besides, the active layer morphology is a key factor for the efficiency of OSCs [1,12-13], and recent studies have evidenced that dispersity, molecular weight and regioregularity of P3HT strongly influence the P3HT:PCBM active layer morphology and consequently the performances [14-16].

(iii) Lastly interfaces are known to limit OSCs lifetimes [17-19]. In particular, recently published results have shown that the PEDOT-PSS layer is susceptible to induce the degradation of the active layer [17]. The devices were irradiated without cathode and so the photodegradation of the active layer at the $\mathrm{Al}$ cathode interface was not investigated. Furthermore, comparing the stability of active layers unconfined or confined by an Al cathode, phase segregation was reported to occur at longer time in the latter case due to the confining effects of the Al cathode [12, 20-21].

In this work, we examine the photochemical stability of P3HT:PCBM blended films prepared by changing the P3HT type. Furthermore, we investigate these blends either confined or unconfined by an Al cathode and a PEDOT:PSS layer during photochemical ageing. Samples were submitted to accelerated tests under UV-visible light at $60^{\circ} \mathrm{C}$ in the absence of oxygen. A set of experiments was developed to monitor the modifications during ageing, i.e., UV-visible spectroscopy, microfluorescence and AFM (Atomic Force Microscopy). 


\section{Experimental}

\section{Materials}

P3HT was purchased from BASF (so-called BA02), Sigma Aldrich (AL02) and Rieke Metals, Inc. $(\mathrm{RE})$ respectively. The structural parameters of the three materials are reported in Table 1 that gives both the data obtained from the producers and those determined in the lab. PCBM was purchased from American Dye Source. Poly(3,4-ethylenedioxythiophene) polystyrenesulfonate (PEDOT:PSS, Baytron PH) was purchased from HC Stark. Anhydrous chlorobenzene (HPLC grade) was purchased from Sigma-Aldrich.

\section{Table 1}

\section{Samples preparation.}

Two solutions (40 $\mathrm{mg} \mathrm{mL}^{-1}$ ) of $\mathrm{P} 3 \mathrm{HT}$ and PCBM respectively were prepared. A first series of P3HT and P3HT:PCBM blend films were prepared via spin coating (G3P-8 Spincoat, Cookson Electronics Equipment) on $\mathrm{KBr}$ and glass plates from chlorobenzene solutions. Sample thickness $(\sim 150 \mathrm{~nm})$ was determined by profilometry using a KLA Tencor Alpha-step IQ apparatus.

A second series of samples having a glass/ITO/PEDOT:PSS/P3HT:PCBM/Al structure were prepared. Glass coated ITO (100 nm thickness) substrates from Merck Display Technology were cleaned in an ultrasonic bath with acetone and isopropanol, and then rinsed in deionised water. They were finally exposed to UV-ozone for $5 \mathrm{~min}$. Patterning of the anode has been obtained by chemical etching in warm $\mathrm{HCl}$ solution. A $30 \mathrm{~nm}$ thick PEDOT:PSS film was then spin-coated and dried under air for $40 \mathrm{~min}$ at $180{ }^{\circ} \mathrm{C}$. The P3HT:PCBM (1:1 and 1:0.8) active layer $(\sim 150 \mathrm{~nm})$ was next deposited by spin-coating in a glove box. Finally, $\sim 100$-nm-thick Al cathode was deposited on the P3HT/PCBM layer under high vacuum using a thermal evaporator. For thermal annealing, the completed devices were placed directly onto a hot plate and heated at 
$150{ }^{\circ} \mathrm{C}$ for $30 \mathrm{~min}$ (AL02) or $50 \mathrm{~min}$ (BA02 and RE) under inert atmosphere immediately after spin-coating.

\section{Photo-Ageing.}

Irradiations were carried out in a SEPAP 12/24 unit [22]. This apparatus was designed for the study of polymer photodegradation under artificial ageing conditions corresponding to medium-acceleration conditions. The chamber was made of a square reactor equipped with four medium-pressure mercury lamps (Novalamp RVC 400W) situated in vertical positions at each corner of the chamber. Wavelengths below $295 \mathrm{~nm}$ were filtered by the glass envelope of the sources. In the centre of the chamber, the samples were fixed on a rotating carousel with a 13 $\mathrm{cm}$ diameter. In this series of experiments, the temperature was fixed at $60{ }^{\circ} \mathrm{C}$. All the exposures were carried out in the absence of oxygen ("photolysis"). To this end, the samples were introduced into borosilicate tubes and sealed under a vacuum of $10^{-3} \mathrm{~Pa}$ using a diffusion vacuum line. The tubes were then placed in the SEPAP 12/24 device.

\section{Samples characterization}

Changes in the UV-visible spectra were followed with a Shimadzu UV-2101PC spectrophotometer equipped with an integrating sphere.

Fluorescence microscopy images were obtained on a Zeiss AxioPlan 2 under bichromatic excitation (405 and $436 \mathrm{~nm}$ ).

A Nanoscope IIIa atomic force microscope from Veeco Instruments was used for AFM analysis of the active layer. Two types of P3HT:PCBM areas were investigated : either near the cathode or below the cathode after removing Al thanks to the scotch-tape method.

\section{PV properties monitoring}

Solar cells were characterized under AM 1.5G illumination at $94 \mathrm{~mW} \mathrm{~cm}^{-2}$ using an Atlas Solar constant 575PV simulator. Current-voltage characteristics were measured via a computercontrolled Keithley SMU 2400 unit. 


\section{Results and Discussion}

\subsection{Evolution of the P3HT thin films deposited on inert substrate}

Before providing the results of the analysis of the photochemical evolution in the absence of oxygen of P3HT:PCBM, it is worth to present the main results related to $\mathrm{P} 3 \mathrm{HT}$ photodegradation in the same irradiation setup. Results obtained with high regioregular P3HT (HR-P3HT, RR: 98\%), namely BA02 and AL02, are compared with P3HT Rieke "E” (RE) (RR: 96\%) used in a previous study [11]. Both the shape of the UV-visible absorption band and the photodegradation rate sensitively depend on the structure of the polymer.

Prior to irradiation, pristine P3HT presented a broad absorption band indicative of an extensive $\pi$-electron delocalisation. Three absorption maxima are observed at $520 \mathrm{~nm}, 552 \mathrm{~nm}$ and 600 $\mathrm{nm}$, the intensity of this latter increasing with the molecular order in the film [23]. It can be observed in Fig. 1a that HR-P3HT (BA02 and AL02, RR: 98\%) has an absorption maximum at $552 \mathrm{~nm}$, and shows an intense feature at $600 \mathrm{~nm}$, which indicates a significantly higher degree of crystallinity compared to P3HT Rieke E (RR: 96\%), which absorption is blue-shifted with $\lambda_{\max }$ value at $520 \mathrm{~nm}$.

\section{Figure 1}

During irradiation, a decay in the intensity of the absorption band at long wavelengths $(\lambda>450$ nm) and a blue shift were observed for the three samples (see for example, evolution of BA02 reported in Fig. 1b). This indicated a reduction of the conjugation length in the macromolecular backbone, which provokes the photobleaching of the polymer. In addition, photolysis altered the degree of interchain order in the microcrystalline domains of P3HT, as evidenced by the progressive disappearance of the shoulders at 552 and $600 \mathrm{~nm}$. 
The absorbance evolution was monitored versus the ageing time. The absorbance at the initial maximum (552 $\mathrm{nm}$ for BA02 and AL02, $520 \mathrm{~nm}$ for RE) showed a linear decrease during the initial phase of the photodegradation. The degradation rate was determined as the initial slope of the curve $A=f(t)$ (the concentration was obtained taking into account a thickness of $150 \mathrm{~nm}$ and an extinction coefficient of the thiophene unit $\varepsilon=10^{4} \mathrm{M}^{-1} \mathrm{~cm}^{-1}$ [24]). The photodegradation rates $\left(\mathrm{mol} \mathrm{cm} \mathrm{c}^{-3} \mathrm{~h}^{-1}\right)$ of the three samples are reported in Table 2.

\section{Table 2}

One can observe in Table 2 that high-regioregular P3HT (BA02 and AL02) was photolyzed slower than RE by a factor of about 5 , and that AL02 and BA02 degraded at the same rate. These observations confirm that P3HT is photo-unstable even in absence of oxygen [11], and show that the microstructure of $\mathrm{P} 3 \mathrm{HT}$ has a measurable effect on the photolysis rate.

Such an influence of the microstructure was also reported upon photooxidation experiments [24]. Changing the structure of the polymer from regioregular to regiorandom was shown to significantly increase the photooxidation rate by a factor 5 [24]. Concerning BA02, AL02 and RE, we showed that the photooxidation rate of RE is the double of BA02 and AL02 [unpublished data]. Upon photooxidative experiments, it was suggested that this effect could be related to the higher triplet yield of the regiorandom polymer, a possible pathway being the sensitization of singlet oxygen [24], meanwhile it has been shown that P3HT films are not attack by singlet oxygen [25]. This kind of explanation is not relevant under irradiation in the absence of oxygen. As it was not the goal of this paper, this will not be discussed here but results will be presented in a forthcoming paper.

\subsection{Evolution of the P3HT:PCBM blended films deposited on inert substrate}

We previously showed that the $\mathrm{P} 3 \mathrm{HT}$ degradation rate can be suppressed when $\mathrm{P} 3 \mathrm{HT}$ is blended with PCBM [11], and that the degradation of P3HT was faster when the amount of 
PCBM in the active was reduced [17]. So to observe significant effects after reduced irradiation durations, we decided to prepare P3HT:PCBM (1:0.6) blend samples.

The morphology of solar cells within the bulk heterojunction layer has been shown to be strongly affected by thermal annealing treatments [26-28]. The UV-visible spectra of P3HT:PCBM (1:0.6) deposited on KBr substrate are shown in Figure 2a. The first (black line) is where the active layer was simply spin coated onto the glass substrate. The second (dashed line) is where the active layer was annealed under a nitrogen atmosphere at $150^{\circ} \mathrm{C}$ for 30 min. For the thermally annealed active layer, the shoulder centered at $605 \mathrm{~nm}$ arises from the crystallization of the $\mathrm{P} 3 \mathrm{HT}$ and further enhances the absorption in the visible range.

\section{Figure 2}

Figure $2 \mathrm{~b}$ show the absorption spectra of P3HT:PCBM blend films after annealing treatment for the three P3HT. The cristallinity of A102 and RE in blend films is observed to be roughly the same and quite lower than that of BA02 blend films. But the cristallinity of BA02 and AL02 was shown to be equivalent in pristine films, and quite higher than that of RE (see Fig. 1a). The different behavior of the two high-regioregular P3HT in pristine and blend films was attributed to difference in their respective molecular weight: BA02 has a quite lower molecular weight $\left(26000 \mathrm{~g} \mathrm{~mol}^{-1}\right)$ than AL02 $\left(98000 \mathrm{~g} \mathrm{~mol}^{-1}\right)$.

\section{Table 3}

Table 3 compares the photolysis rates of the P3HT:PCBM blend films using BA02, AL02 and RE. As previously observed for pristine P3HT thin films (see Table 2), the photolysis rates of high-regioregular P3HT(AL02 and BA02):PCBM blend films is slower than the one of P3HT(RE):PCBM.

\subsection{Evolution of the P3HT:PCBM blended films deposited on the PEDOT:PSS layers}


From this section, only the two high-regioregular P3HT (AL02 and BA02) were used because of their highest photostability. We first compared the UV-visible spectra of the P3HT:PCBM (1:0.6) blends deposited on glass/ITO and glass/ITO/PEDOT:PSS. It is noteworthy to recall that the PEDOT:PSS film was dried for $40 \mathrm{~min}$ at $180^{\circ} \mathrm{C}$ before the deposit of the P3HT:PCBM layer.

Before exposure, no significant differences were evidenced between the UV-visible spectra of the glass/ITO/P3HT:PCBM and the glass/ITO/PEDOT:PSS/P3HT:PCBM samples.

The glass/ITO/PEDOT:PSS/P3HT:PCBM samples were submitted to irradiation in the absence of oxygen for $500 \mathrm{~h}$. Irradiation of glass/ITO/PEDOT:PSS/P3HT:PCBM was observed to provoke the same weak decrease of the UV-visible absorbance as the one previously reported for the glass/ITO/P3HT:PCBM samples (see section 3.2). This result was not unexpected as it was previously shown that the degradation of the P3HT:PCBM active layer induced by the PEDOT:PSS layer can be suppressed when the annealing temperature of the PEDOT:PSS layer was carried out at high temperature $\left(180^{\circ} \mathrm{C}\right.$ instead of $\left.140^{\circ} \mathrm{C}\right)$ [17].

\subsection{Analysis of the active layer in the cell confined and unconfined by an AL cathode}

We then focused on the behavior and photostability of high-regioregular P3HT using PCBM as the acceptor in bulk heterojunction devices with a general structure of glass/ITO/PEDOT:PSS/P3HT:PCBM/Al. The P3HT:PCBM ratio was either 1:1 or 1:0.8.

We analyzed before and after exposure the active layer unconfined by the Al cathode (i.e. free space between the two cathodes) or confined by the cathode after its removal by scotchtapping. Optical and fluorescence microscopy were used to provide both a qualitative and quantitative inspection of the P3HT:PCBM blend morphology.

A sample annealed for $100 \mathrm{~h}$ at $100{ }^{\circ} \mathrm{C}$ served as a reference for an accelerated ageing test because prolonged annealing has previously been shown to provoke phase separation, leading 
to the formation of PCBM domains up to $100 \mu \mathrm{m}$ in size [30]. The fluorescence properties of P3HT and PCBM allowed for characterization of spatial variations in the emission [29], so measurements were also performed on pure P3HT and pure PCBM. In the case of the aged sample, the formation of dark domains was observed in the transmission and fluorescence images (Fig. 3). Emission spectra $\left(\lambda_{\mathrm{exc}}=405\right.$ and $\left.436 \mathrm{~nm}\right)$ confirmed that these domains were PCBM crystals dispersed within a P3HT-rich matrix.

\section{Figure 3}

AFM offers a second means to characterize the surface of the active layer [31]. We observed in the phase images the presence of large features which correspond to PCBM aggregates (Figure 4).

\section{Figure 4}

\subsubsection{Influence of the P3HT-type on the morphology of P3HT:PCBM blend films unconfined and confined by an Al cathode}

The impact of the composition and preparation of the active layer on the device stability was studied. Four different P3HT:PCBM devices were prepared by changing the P3HT type (AL02 and BA02) and the P3HT:PCBM weight ratio (1:1 and 1:0.8). It is noteworthy that with some optimization (duration of the annealing treatment after cathode evaporation) similar peak performances were attained for the four devices.

We first compared the P3HT:PCBM blend films confined or unconfined by the Al cathode before exposure. The anode interface is the same in both cases. The difference between these two types of samples is that with the former, the active layer was confined by the cathode during annealing treatment. 
The UV-visible spectra of confined (after cathode removal) and unconfined P3HT:PCBM were compared. Figure 5 shows that the cristallinity of P3HT (band at $605 \mathrm{~nm}$ ) was the same in both samples but that the PCBM content, determined by the intensity of the band at $330 \mathrm{~nm}$, was lower in the confined sample suggesting a probable diffusion of PCBM upon the evaporation of the $\mathrm{Al}$ layer and the annealing treatment.

\section{Figure 5}

Optical micrographs were used to provide a qualitative analysis of the active layer morphology around the cathodes. We observed the presence of needlelike crystals which were attributed to PCBM thanks to microfluorescence analysis. The surface of the active layer was also characterized by AFM, which allowed us to confirm the presence of PCBM crystals between the cathodes. PCBM crystals were not homogeneously distributed over the entire surface and were observed to be greater on the edges of the devices.

Optical micrographs also allowed evidencing the presence of a diffusion layer near the cathode interface, which was evidenced to be P3HT-rich thanks to microfluorescence analysis.

The influence of the P3HT-type (BA02 and AL02) and of the P3HT:PCBM ratio (1:1 or 1:0.8) were analyzed. Microfluorescence spectra recorded between the cathodes (Figure 6a) showed that AL02 fluorescence in P3HT:PCBM 1:0.8 was the highest indicating that a high P3HT molecular weight favored phase separation. This behavior was also evidenced by AFM images of the top surface of the P3HT(BA02):PCBM (Fig. 6b) and P3HT(AL02):PCBM blend films (Fig. 6c). For P3HT(BA02):PCBM film, the PCBM is dispersed uniformly throughout the film and the contrast between P3HT and PCBM is not easily detected. On the opposite, for P3HT(AL02):PCBM film, the phase separation is strong and the image (Fig. 6c) shows nanocrystallites of PCBM.

Figure 6 
Lastly, micro-fluorescence analyses were performed at the surface of the P3HT:PCBM blend film confined by the Al cathode. Emission spectra reported in Figure 7 showed that the interface is a P3HT-rich matrix.

\section{Figure 7}

All these results suggest that the devices were not optimized (even if optimization of the devices was made in the lab). It was reported that ideal P3HT:PCBM bulk heterojunction solar cells need PCBM at the surface to be in contact with the cathode, in order to obtain an efficient extraction of electrons from the device [32,33]. Upon $\mathrm{Al}$ evaporation and subsequent annealing treatment, PCBM was suspected to diffuse from "under the cathode" areas to "between the cathodes" areas, and finally to the edges of our devices. Although facile solution-phase fabrication is one of the main advantages of organic solar cells, it is well-known that devices are sensitive to small variations in the processing conditions [32]. In the case of our samples, we tried to identify the parameters which led to low-performing devices. We believe that the first parameter was the solution concentration. Whereas usually mixtures of P3HT:PCBM ( 10mg:10mg)/mL chlorobenzene are used, in this study mixtures of P3HT:PCBM (20mg:20mg)/mL chlorobenzene were prepared. The second parameter was related to the regioregularity of P3HT. Indeed it has been shown that crystallization-driven phase separation in P3HT:PCBM blend films is enhanced by the crystalline order of the polymer backbone [34].

\subsubsection{Impact of continuous UV-visible light irradiation in the absence of oxygen on devices}

Devices were then introduced in tubes sealed under vacuum and submitted to accelerated photo-ageing in the SEPAP 12/24 for $500 \mathrm{~h}$. Unfortunately, it was not possible to measure the photovoltaic performances as $\mathrm{Al}$ cathodes were too fragile and broke after $500 \mathrm{~h}$ exposure (see Figure 8). 


\section{Figure 8}

So we prepared a new set of samples with a reinforced cathode using only BA02 in P3HT:PCBM (1:0.8) active layers and decided to stop the exposure a first time after very short irradiation durations $(100 \mathrm{~h})$ in the absence of oxygen. The performances of these devices with a structure glass/ITO/PEDOT:PSS/P3HT:PCBM/Al are reported in Table 4.

\section{Table 4}

The active layer was analyzed by UV-visible spectroscopy, microfluorescence and AFM before and after ageing. Photo-ageing was observed to provoke a loss of the photovoltaic performances (see table 4) but no significant modification in the UV-visible spectra was monitored. It is important to note, that an increase of the fluorescence intensity was observed, suggesting a phase separation between P3HT and PCBM.

\section{Figure 9}

This result was confirmed by AFM tapping-mode images of the top surface. The picture (Fig. 9 after exposure, and see Fig. $6 \mathrm{~b}$ before exposure) revealed that after exposure the surface of the active layer was nearly entirely composed of P3HT. A non-expected result was also observed, the total loss of the efficiency in less than 100 hours of exposure. This result could be related to cracks of the cathodes, which accounted for the loss of the photovoltaic properties as reported in Table 4. Cracks could be associated to the modification of the active layer and more specially to the P3HT nanocristallinity exhibiting a "rice-grain"-like structure [32], as it can be observed in the Figure 9. This kind of phenomenon implicates a dramatic increase of the internal strain into the active layer [35]. When the strain reached a maximum, the P3HT: PCBM bulk heterjunction could not relax and cracks are formed. It is obvious that cracks appeared at the "Achilles' heel" of the device, which is the active layer/cathode interface. 


\section{Conclusion}

In summary, we have shown that regioregularity is an important variable that can drastically affect the polymer photostability. For pristine polymer films and P3HT:PCBM blend films, a more regioregular polymer gives a better photostability. However, in P3HT:PCBM solar cells, high-regioregular P3HT induce a phase segregation with PCBM upon thermal annealing, with the formation of large PCBM crystals. Furthermore, it was shown that the surface of the active layer below the Al cathode was dominated by P3HT, which is detrimental for efficient electrons extraction at the cathode. In addition, long time exposure to UV-visible light induced the formation of cracks that could be linked to the modifications of the active layer nanomorphology. Our results should be confirmed by studying less regioregular P3HT. All these results emphasize the need to better control solvent evaporation during spin-coating and to improve the mechanical behavior of the active layer/cathode interface.

\section{Acknowledgement.}

This work was supported by the French ANR (Agence Nationale pour la Recherche) under

Grant Name VISTASOLOR. The authors thank Ghislain Boloma from XLIM (Limoges, France) for his help with devices preparation and testing. 


\section{References}

[1] M. Jørgensen, K. Norrman, F.C. Krebs, Solar Energy Materials and Solar Cells 92 (7), 686 (2008)

[2] H. Hoppe, N.S. Sariciftci, J. Mater. Res. 19, 1924 (2004)

[3] K.M. Coakley, M.D. McGehee, Chem. Mater. 16 (23), 4533 (2004)

[4]

http://www.konarka.com/index.php/site/pressreleasedetail/konarkas_power_plastic_achieves_ world_record_83_efficiency_certification_fr

[5] H. Spanggaard, F.C. Krebs, Solar Energy Materials and Solar Cells 83 (2-3), 125 (2004)

[6] F.C. Krebs, K. Norrman, Prog. Photovol. Res. Appl. 15, 697 (2007).

[7] M. Manceau, A. Rivaton, J-L. Gardette, S. Guillerez, N. Lemaitre, Polymer Degradation and Stability 94, 898 (2009)

[8] A. Rivaton, S. Chambon, M. Manceau, J-L. Gardette, N. Lemaître, S. Guillerez, Polymer Degradation and Stability 95, 278 (2010)

[9] M. Manceau, J. Gaume, A. Rivaton, J.-L. Gardette, G. Monier, L. Bideux, Thin Solid Films 518, $7113(2010)$

[10] S. Chambon, A. Rivaton, J-L. Gardette, M. Firon, Solar Energy Materials and Solar Cells 92, $785(2008)$

[11] M. Manceau, S. Chambon, A. Rivaton, J-L. Gardette, S. Guillerez, N. Lemaitre, Solar Energy Materials and Solar Cells 94, 1572 (2010)

[12] X. Yang, J. Loos, Macromolecules 40, 1353 (2007)

[13] H. Hoppe, N.S. Sariciftci, J. Mater. Chem. 1645 (2006)

[14] R.C. Hiorns, R. de Bettignies, J. Leroy, S. Bailly, M. Firon, C. Sentein, A. Khoukh, H. Preud'homme, C. Dagron-Lartigau, Adv. Funct. Mater. 16, 2263 (2006) 
[15] W. Ma, J.Y. Kim, K. Lee, A.J. Heeger, Macromol. Rapid Commun. 28, 1776 (2007)

[16] M. Urien, L. Bailly, L. Vignau, E. Cloutet, A. de Cuendias, G. Wantz, H. Cramail, L. Hirsch, J-P. Parneix, Polym. Int. 57 (5), 764 (2008)

[17] M. Manceau, A. Rivaton, J-L. Gardette, S. Guillerez, N. Lemaître, Solar Energy Materials and Solar Cells 95, 1315 (2011)

[18] T.P. Nguyen, P. Le Rendu, P.D. Long, S.A. De Vos, Surface and Coatings Technology 180-181, 646 (2004)

[19] B. Johnev, M. Vogel, K. Fostiropoulos, B. Mertesacker, M. Rusu, M.C. Lux-Steiner, A. Weidinger, Thins Solid Films 488, 270 (2005)

[20] H. Kim, W-W So, S-J Moon, Solar Energy Materials and Solar Cells 91, 581 (2007)

[21] D. Chen, A. Nakahara, D. Wei, D. Nordlund, T.P. Russell, Nano Lett. 11, 561 (2011)

[22] J. Lemaire, R. Arnaud, J-L. Gardette, Rev Gen Caout Plast 613, 87 (1981)

[23] P.J. Brown, D.S. Thomas, A. Köhler, J.S. Wilson, J-S Kim, C.M. Ramsdale, H. Sirringhaus, R.H. Friend, Phys. Rev. B 67, 064203 (2003)

[24] H. Hintz, H-J. Egelhaaf, L. Luer, J. Hauch, H. Peisert, T. Chasse, Chem. Mater. 23, 145 (2011)

[25] M. Manceau, A. Rivaton, J-L. Gardette, Macromolecular Rapid Communications, 291823 (2008)

[26] G. Janssen, A. Aguirre, E. Goovaerts, P. Vanlaeke, J. Poortmans, J. Manca, Eur. Phys. J. Appl. Phys. 37, 287 (2007)

[27] T.J. Savenije, J.E. Kroeze, X. Yang, J. Loos, Adv. Funct. Mater. 15, 1260 (2005)

[28] S. Ebadian, B. Gholamkhass, S. Shambayati, S. Holdcroft, P. Servati, Solar Energy Materials and Solar Cells 94, 2258 (2010)

[29] A. Swinnen, I. Haeldermans, M. Vande Ven, J. D’Haen, G. Vanhoyland, S. Aresu, M. D’Olieslaeger, J. Manca, Adv. Funct. Mater. 16, 760 (2006) 
[30] S. Bertho, G. Janssen, T.J. Cleij, B. Conings, W. Moons, A. Gadisa, J. D’Haen, E. Goovaerts, L. Lutsen, J. Manca, D. Vanderzande, Sol. Energy Mater. Sol. Cells 92, 753 (2008) [31] M. T. Dang, L. Hirsch, G. Wantz, Adv. Mater., 23, 3597 (2011)

[32] B. Tremolet de Villers, C.J. Tassone, S.H. Tolbert, B.J. Schwartz, J. Phys. Chem. Lett. 113, 18978 (2009)

[33] A.J. Parnell, A.D.F. Dunbar, A.J. Pearson, P.A. Staniec, A.J.C. Dennison, H. Hamamatsu, M.W.A. Skoda, D.G. Lidzey, R.A.L. Jones, Adv. Mater. 22, 2444 (2010)

[34] C.H. Woo, B.C. Thompson, B.J. Kim, M.F. Toney, J.M.J. Fréchet, J. Am. Chem. Soc. 130, $16324(2008)$

[35] J.-F. Larché, P.-O. Bussière, J.-L. Gardette, Polymer Degradation and Stability, 95, 1810 (2010) 


\section{Figure Captions}

Figure 1. (a) UV-visible spectra of BA02 (black line), AL02 (dashed line) and Rieke E (grey line) pristine $\mathrm{P} 3 \mathrm{HT}$ thin films deposited on $\mathrm{KBr}$ substrate. (b) Evolution of the UV-visible spectra of BA02 thin films deposited on $\mathrm{KBr}$ substrate upon irradiation.

Figure 2. (a) UV-visible spectra of P3HT(BA02):PCBM thin films deposited on $\mathrm{KBr}$ substrate before (black line) and after (dashed line) annealing. (b) UV-visible spectra of BA02 (black line), AL02 (dashed line) and RE (grey line) P3HT:PCBM blend films deposited on $\mathrm{KBr}$ substrate after annealing (spectra were normalized to facilitate the comparison).

Figure 3. (a) Transmission images of the top surface of a P3HT:PCBM film annealed for $100 \mathrm{~h}$ at $100{ }^{\circ} \mathrm{C}$. (b) Emission spectra of two domains of the P3HT:PCBM sample annealed for $100 \mathrm{~h}$ at $100{ }^{\circ} \mathrm{C}$. Emission spectra of pure P3HT $(\square)$ and pure $\operatorname{PCBM}(\triangle)$.

Figure 4. AFM tapping-mode phase images of the top surface of (a) a P3HT:PCBM film annealed for $100 \mathrm{~h}$ at $100{ }^{\circ} \mathrm{C}$, and (b) pure PCBM.

Figure 5. UV-visible spectra of unconfined (black line) and confined (dashed line) P3HT(AL02):PCBM film.

Figure 6. (a) Emission spectra of P3HT(AL02):PCBM (ם) and P3HT(BA02):PCBM ( $\mathbf{\Delta}$ ) comparing ratio 1:1 (fill) and ratio 1:0.8 (empty). AFM tapping-mode phase images of the top surface of unconfined (b) P3HT(BA02):PCBM film, (c) P3HT(AL02):PCBM film. 
Figure 7. Emission spectra of pristine P3HT(AL02) (black line), P3HT(AL02):PCBM (1:0.8 ) blend film unconfined $(\nabla)$ and confined $(\square)$ by the $\mathrm{Al}$ cathode.

Figure 8. Devices after 500 hours of exposure in the absence of oxygen.

Figure 9. AFM tapping-mode phase images of the top surface of P3HT(BA02):PCBM film after $100 \mathrm{~h}$ exposure. 


\section{Table Captions}

Table 1. Data obtained from the producers for the three P3HTs, and results obtained in the lab.

Table 2. Photodegradation rates of $\mathrm{P} 3 \mathrm{HT}$ pristine thin films expressed in $\mathrm{mol} \mathrm{cm}^{-3} \mathrm{~h}^{-1}$.

Table 3. Photodegradation rates of P3HT/PCBM (1:0.6) thin films expressed in $\mathrm{mol} \mathrm{cm}^{-3} \mathrm{~h}^{-1}$.

Table 4. Characteristic parameters of the devices before exposure and after 100h exposure. 
Figure 1
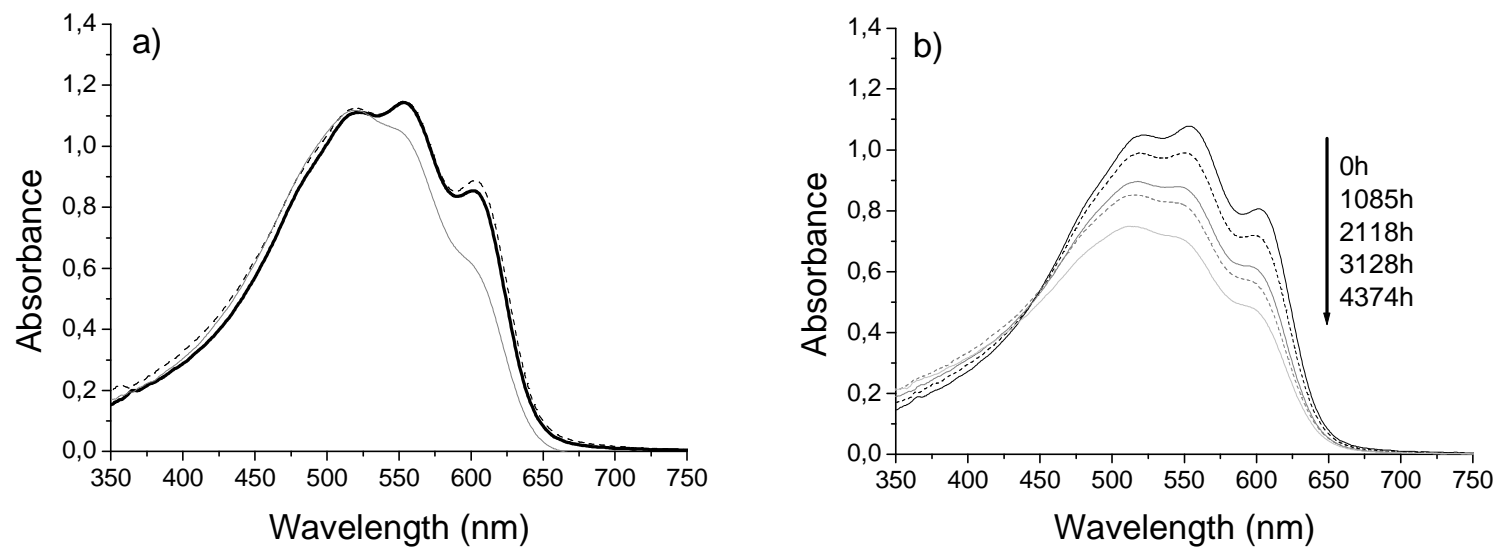
Figure 2
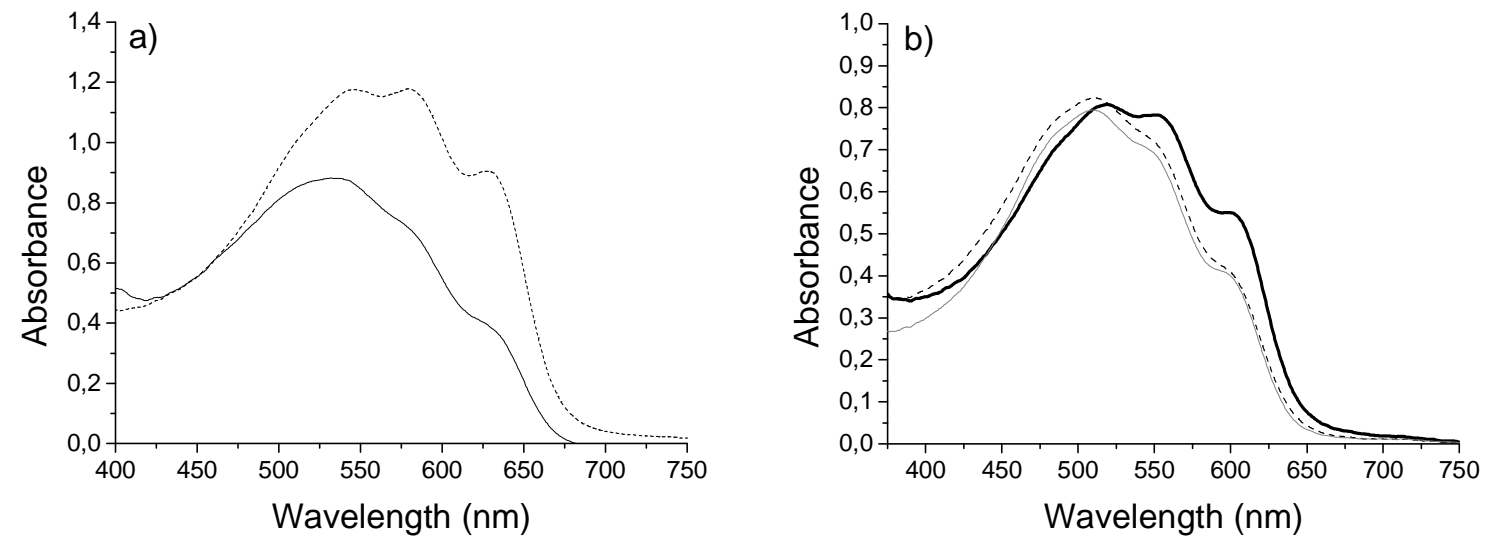
Figure 3

a)

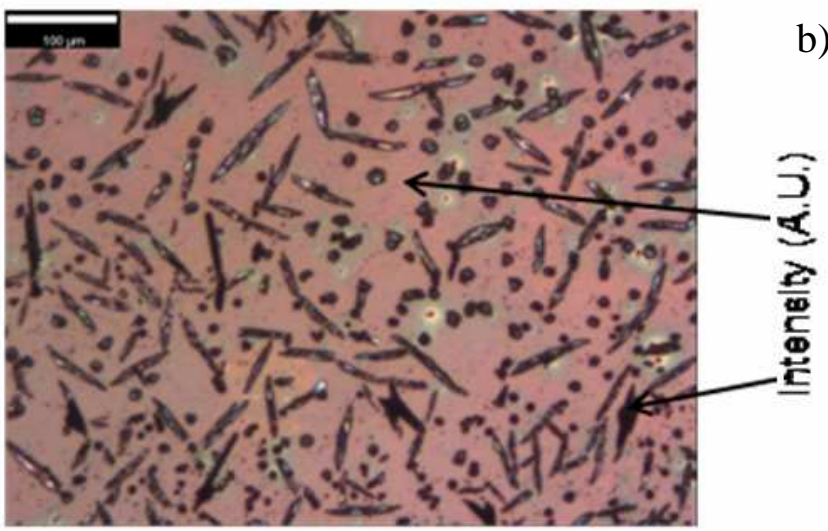

b) 5

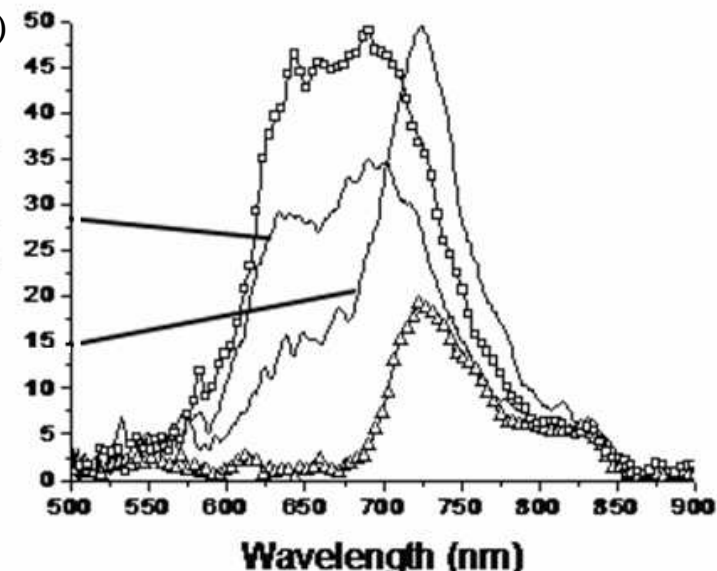


Figure 4
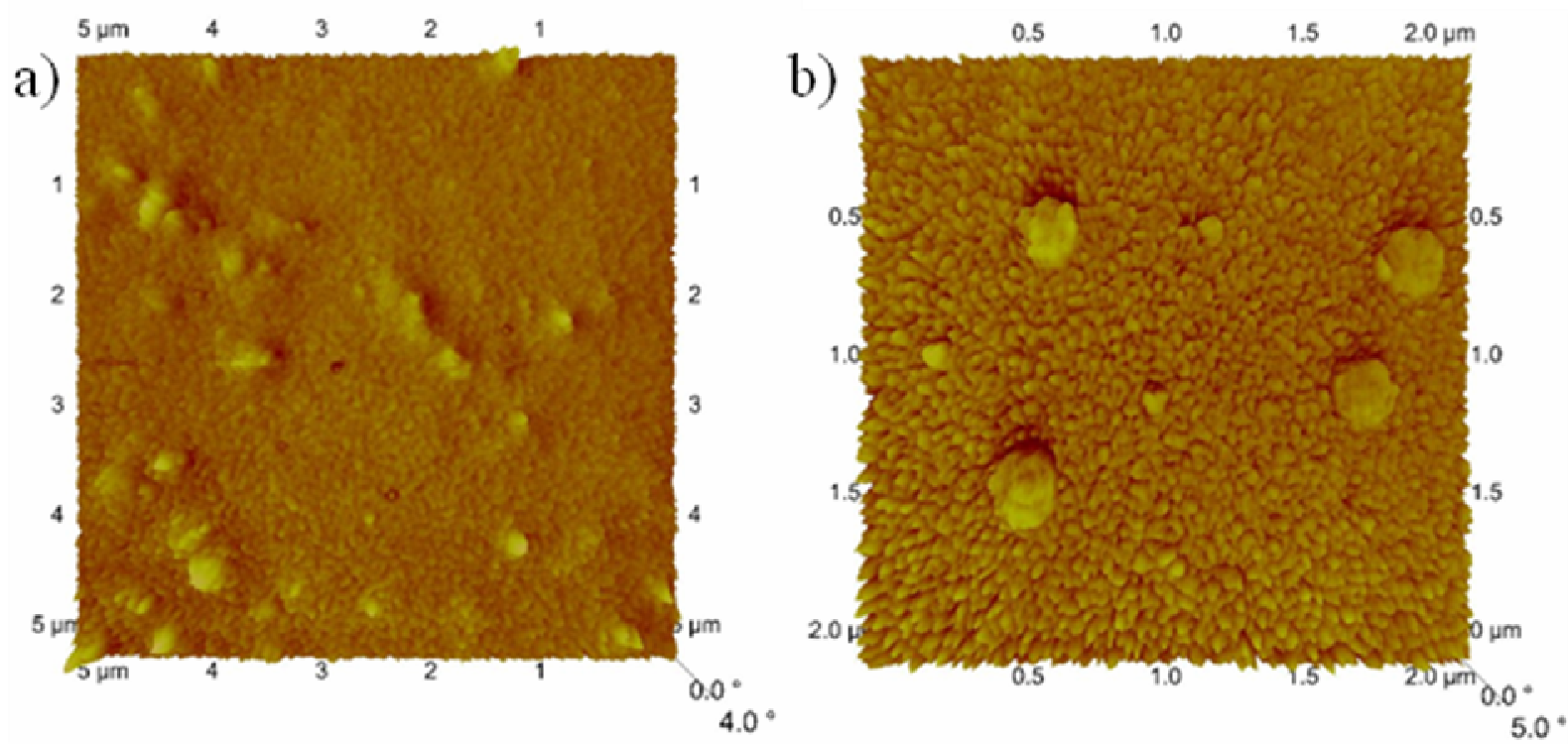
Figure 5

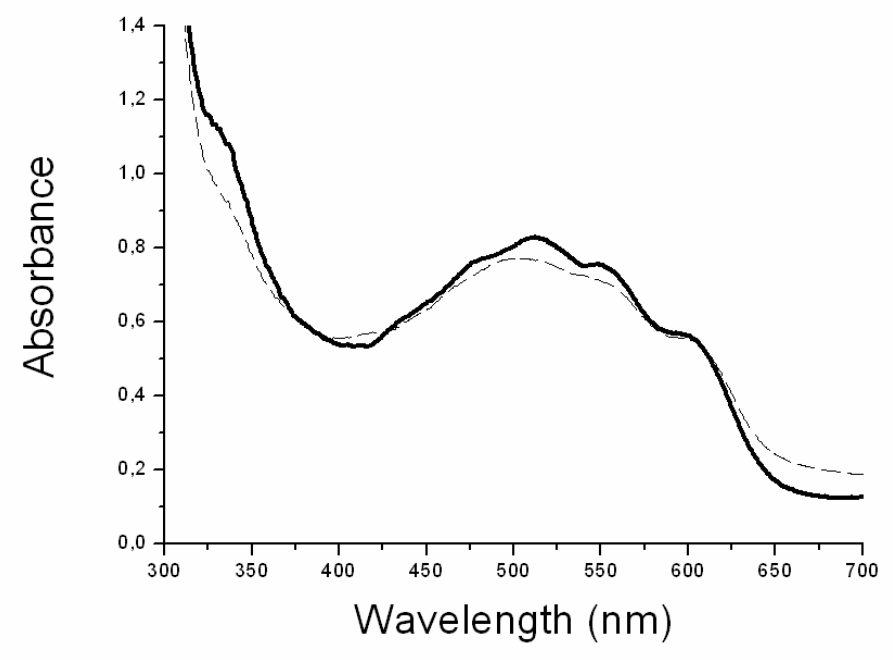


Figure 6

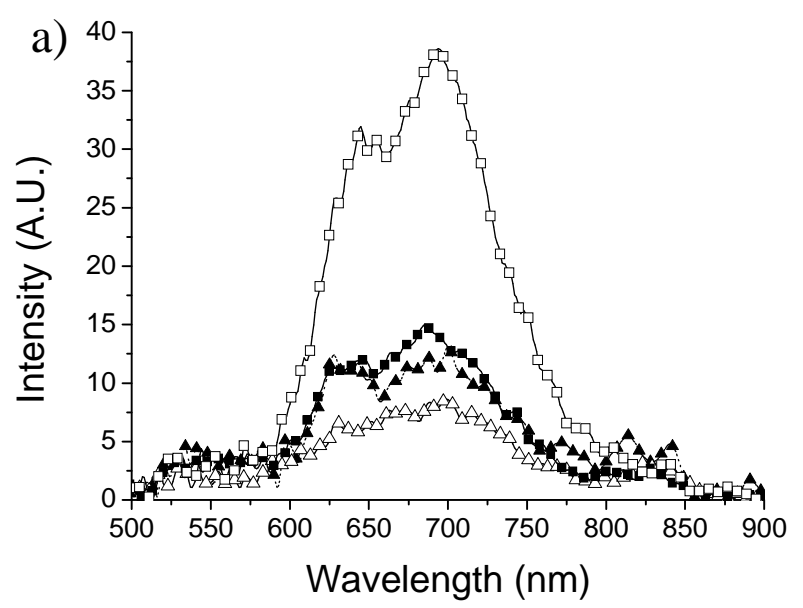

b)

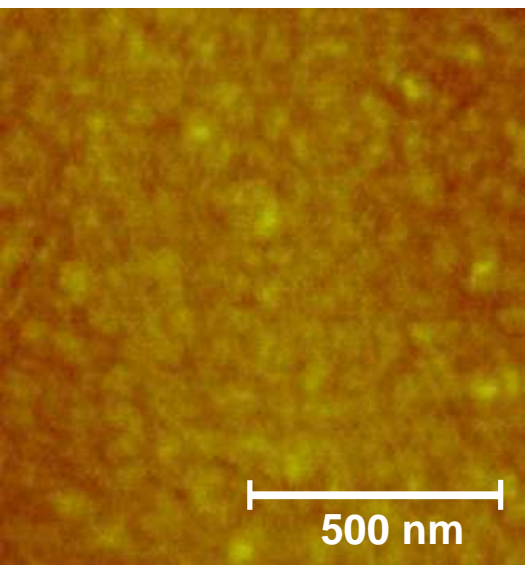

c)

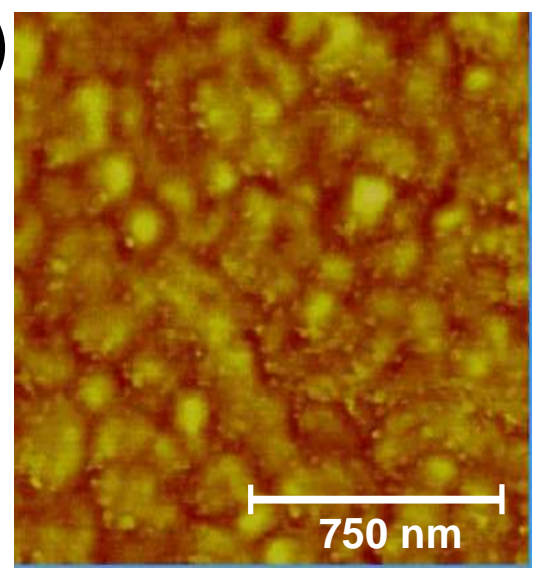


Figure 7

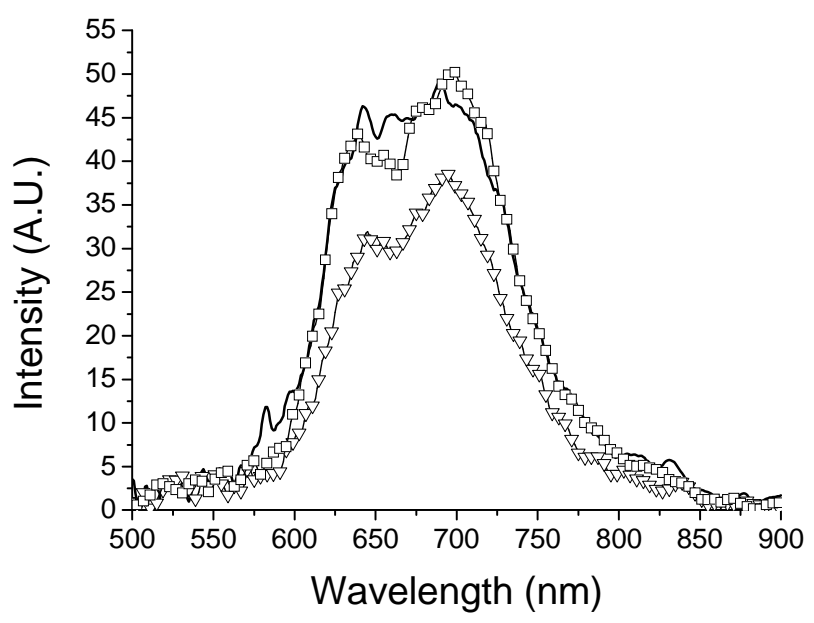


Figure 8

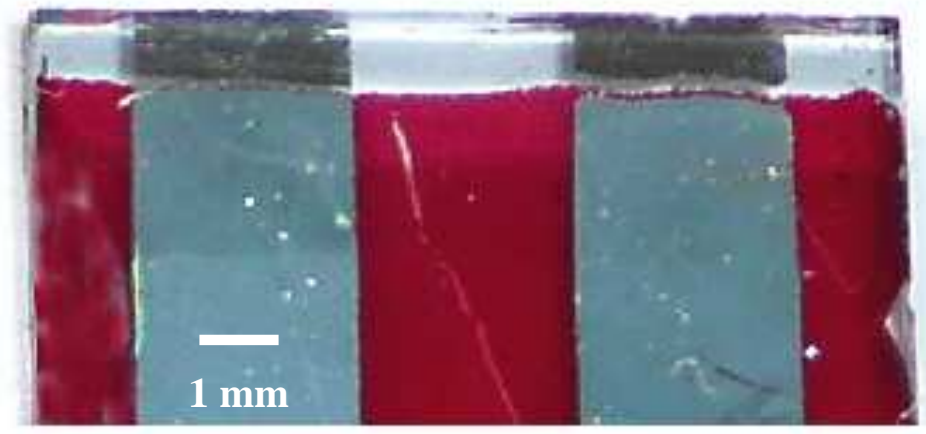


Figure 9

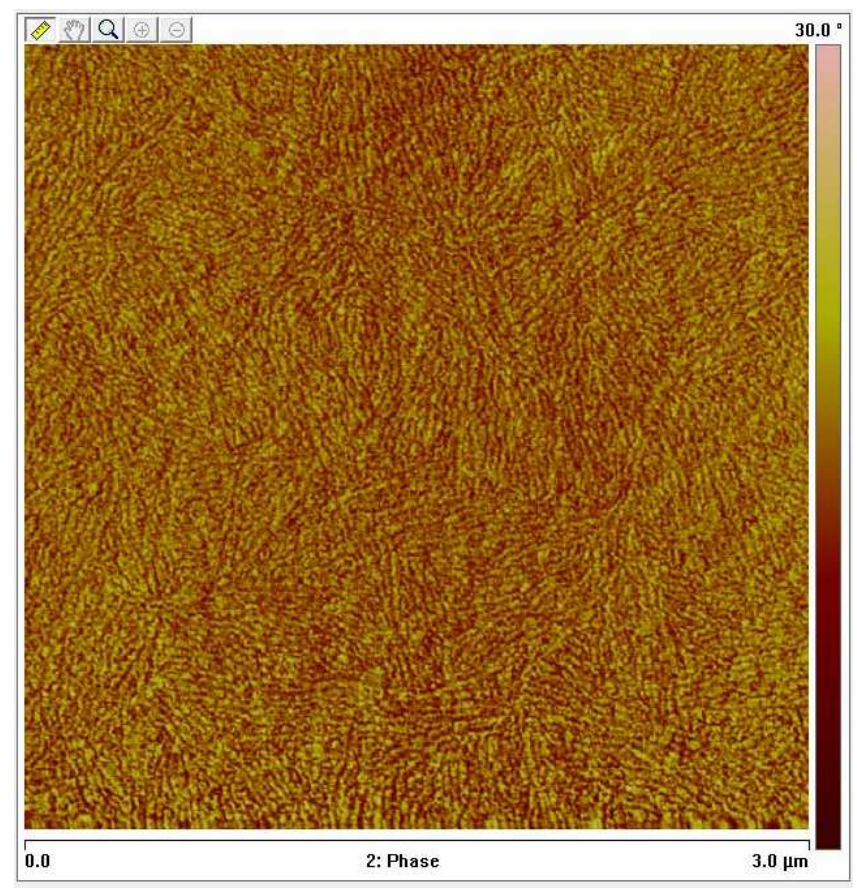


Table1

\begin{tabular}{|c|c|c|c|c|c|c|}
\cline { 2 - 7 } \multicolumn{1}{c|}{} & \multicolumn{2}{c|}{ BA02 } & \multicolumn{2}{c|}{ AL02 } & \multicolumn{2}{c|}{ RE } \\
\cline { 2 - 7 } \multicolumn{1}{c|}{} & Suppliers & our Lab & Suppliers & our Lab & Suppliers & our Lab \\
\hline $\begin{array}{c}\text { Molecular } \\
\text { weight }\left(\mathrm{g} \mathrm{mol}^{-1} \text { ) }\right.\end{array}$ & $\begin{array}{c}<50000 \\
\text { (other grade } \\
\text { possible) }\end{array}$ & $\begin{array}{c}26000 \\
\pm 1000\end{array}$ & $45-65000$ & $\begin{array}{c}90000 \\
\pm 3000\end{array}$ & 50000 & 42000 \\
\pm 3000 \\
\hline Regioregularity & $>98 \%$ & $97.7 \% \pm 0,4 \%$ & $\geq 98 \%$ & $97.5 \% \pm 0.5 \%$ & $90 \%$ & $96.0 \% \pm 0.1 \%$ \\
\hline Dispersity & $\leq 2$ & 1.5 & - & 1.5 & - & 1.7 \\
\hline
\end{tabular}

Table 1. Data obtained from the producers for the three P3HTs, and results obtained in the lab. 
Table 2

\begin{tabular}{|c|c|c|c|}
\cline { 2 - 4 } \multicolumn{1}{c|}{ P3HT pure } & BA02 & AL02 & RE \\
\hline $\begin{array}{c}\text { Photodegradation rate } \\
\left(\mathbf{m o l ~ c m}^{-3} \mathbf{h}^{-1}\right)\end{array}$ & $0.70 \times 10^{-6}$ & $0.71 \times 10^{-6}$ & $3.30 \times 10^{-6}$ \\
\hline
\end{tabular}

Table 2. Photodegradation rates of P3HT pristine thin films. 
Table 3

\begin{tabular}{|c|c|c|c|}
\cline { 2 - 4 } \multicolumn{1}{c|}{ P3HT/PCBM } & BA02 & AL02 & RE \\
\hline $\begin{array}{c}\text { Photodegradation rate } \\
\left(\mathbf{m o l ~ c m}^{-3} \mathbf{h}^{-\mathbf{1}}\right)\end{array}$ & $0.44 \times 10^{-6}$ & $0.41 \times 10^{-6}$ & $0.55 \times 10^{-6}$ \\
\hline
\end{tabular}

Table 3. Photodegradation rates of P3HT/PCBM (1:0.6) thin films. 
Table 4

\begin{tabular}{|c|c|c|c|c|}
\cline { 2 - 5 } \multicolumn{1}{c|}{} & Jcc (mA/cm $\left.\mathbf{( m}^{2}\right)$ & Voc $(\mathbf{V})$ & FF & $\boldsymbol{\eta}$ \\
\hline $\begin{array}{c}\text { P3HT(BA02):PCBM (1:1) } \\
\text { before exposure }\end{array}$ & -7.19 & 0.61 & 0.44 & 1.93 \\
\hline $\begin{array}{c}\text { P3HT(AL02):PCBM (1:1) } \\
\text { after 100 h exposure }\end{array}$ & 0 & 0.31 & 0.20 & 0 \\
\hline
\end{tabular}

Table 4. Characteristic parameters of the devices before exposure and after $100 \mathrm{~h}$ exposure. 